\title{
Natural rubber degradation by laccase and manganese peroxidase enzymes of Penicillium chrysogenum
}

\author{
G. Nayanashree $\cdot$ B. Thippeswamy
}

Received: 17 January 2014/Revised: 2 April 2014/ Accepted: 9 June 2014/Published online: 25 July 2014

(C) Islamic Azad University (IAU) 2014

\begin{abstract}
Natural rubber (NR), or cis-1,4 poly-isoprene, is one of the most important biopolymers. For almost a 100 years, million tons of NR-derived products have been produced by humankind as it is very elastic in nature. These products are mainly made up of NR, which is obtained from the latex of tree Hevea brasiliensis commonly called rubber tree. After usage of these NR products, the disposal of these products is the worldwide solid waste problem. To reduce this problem, microbial degradation of the product should be developed. Microbial degradation is mainly carried out by various microorganisms such as bacteria and fungi. Rubberdegrading organisms were isolated by soil burial method. In the isolated organism, Penicillium chrysogenum effectively degraded the NR sample, and enzyme responsible for degradation was also studied. The present study has showed that it is possible to use this strain to degrade the NR.
\end{abstract}

Keywords Hevea brasiliensis - Laccase · Manganese peroxidase $\cdot$ Penicillium chrysogenum $\cdot$ Polyisoprene . Vulcanization

\section{Introduction}

Natural rubber (NR), or cis-1,4 poly-isoprene, is one of the most important biopolymers. For almost a 100 years,

\section{G. Nayanashree}

Department of Microbiology, Kuvempu University,

Jnanasahyadri, Shankaraghatta, Shivamogga (Dist.) 577451,

Karnataka, India

B. Thippeswamy ( $\square)$

Department of P.G. Studies and Research in Microbiology,

Bio-Science Complex, Kuvempu University, Jnanasahyadri,

Shankaraghatta, Shivamogga (Dist.) 577451, Karnataka, India

e-mail: thippeswamyb205@gmail.com millions of tons of NR-derived products have been produced by humankind. The global rubber consumption is estimated to be 12.5 million metric tons in 2013 of which $65 \%$ were used for tire production and other $35 \%$ is used for the production of other rubber products. These products are mainly made up of NR, which is obtained from the latex of tree Hevea brasiliensis commonly called rubber tree. After use of these products, it accumulates in the environment. Many efforts have been made since 1914 to investigate microbial rubber degradation. However, the biochemical mechanisms of biological NR degradation are still not widely known (Roy et al. 2005).

The present study was taken to isolate the NRdegrading fungi from the soil. Rubber degradation was carried out using rubber discs. In this degradation experiment, Penicillium chrysogenum showed $64.3 \%$ weight loss. Then, further confirmation of rubber degradation was done by Schiff's staining, scanning electron microscopy, Fourier transform-infrared spectroscopy and nuclear magnetic resonance spectroscopy. Enzymes responsible for rubber degradation were screened from $P$. chrysogenum and were identified as laccase and manganese peroxidase. Molecular weight of laccase was determined as $66 \mathrm{kDa}$ and that of manganese peroxidase was $45 \mathrm{kDa}$. It was studied that laccase and manganese peroxidase were the enzymes, which cleaved cis-1,4 poly-isoprene to monomer units.

\section{Materials and methods}

Sample collection

For the isolation of NR-degrading fungi, NR latex and NR sheet samples were collected from rubber plantation and 
brought to the laboratory and preserved in the refrigerator for further use.

Isolation of natural rubber-degrading fungi

For the isolation of NR-degrading microorganisms, soil burial method was followed. NR small discs were weighed and initial weight was recorded. Then, these discs were dumped in the soil and left for a period of 6 months of time interval. These NR discs were removed regularly at time interval of two, four and 6 months, respectively, and weighed. For the isolation of NR-degrading fungi, soil sample and NR samples were plated on the potato dextrose agar media and kept for incubation at room temperature at $27 \pm 2{ }^{\circ} \mathrm{C}$ for 3-4 days for the isolation of fungi (Tsuchii et al. 1996). After incubation period, fungi were identified by staining and based on their microscopic and macroscopic appearance using standard manuals (Ellis 1971, 1976; Pitt 1979; Domsch et al. 1980; Subramanian 1983; Ellis 1997; Gilman 2001; Nagamani et al. 2006).

Plate assay for the screening of microorganisms capable of degrading natural rubber

For the screening of NR-degrading fungi, pure culture isolates were directly inoculated on the sterilized, preweighed NR discs and then kept for incubation for 2 months. Fungi capable of degrading NR utilized NR as sole source of carbon and showed growth on the NR discs. After a time interval of 2 months, NR sample inoculated with organisms was washed thoroughly, dried at $50{ }^{\circ} \mathrm{C}$ in hot air oven for $24 \mathrm{~h}$ and final weight was recorded (Borel et al. 1981).

Screening of natural rubber degradation by using mineral salt medium (MSM)

Natural rubber-degrading ability of the microorganisms was monitored in the laboratory conditions. In this method, mineral salt medium (MSM) was prepared by using the following chemical composition ( $\mathrm{mg} / \mathrm{l})$. Ammonium sulphate $\left(\left(\mathrm{NH}_{4}\right)_{2} \mathrm{SO}_{4}\right)-1,000$, potassium-di-hydrogen phosphate $\left(\mathrm{KH}_{2} \mathrm{PO}_{4}\right)-800$, di-potassium hydrogen phosphate $\left(\mathrm{K}_{2} \mathrm{HPO}_{4}\right)$-200, magnesium sulphate heptahydrate $\left(\mathrm{MgSO}_{4} \cdot 7 \mathrm{H}_{2} \mathrm{O}\right)-500$, ferrous sulphate $\left(\mathrm{FeSO}_{4}\right)-10$, calcium chloride $\left(\mathrm{CaCl}_{2}\right)-50$, nickel sulphate $\left(\mathrm{NiSO}_{4}\right)-32$, sodium borate $\left(\mathrm{Na}_{2} \mathrm{BO}_{7} \cdot \mathrm{H}_{2} \mathrm{O}\right)-7.2$, ammonium hepta molybdate $\left[\left(\mathrm{NH}_{4}\right)_{6} \mathrm{Mo}_{7} \mathrm{O}_{24} \cdot \mathrm{H}_{2} \mathrm{O}\right]-14.4$, zinc chloride
$\left(\mathrm{ZnCl}_{2}\right)$-23, cobalt chloride $\left(\mathrm{CoCl}_{2} \cdot \mathrm{H}_{2} \mathrm{O}\right)-21$, copper chloride $\left(\mathrm{CuCl}_{2} \cdot \mathrm{H}_{2} \mathrm{O}\right)-10$ and manganese chloride $\left(\mathrm{MnCl}_{2} \cdot 4 \mathrm{H}_{2} \mathrm{O}\right)-30$, and the initial $\mathrm{pH}$ of the culture medium was adjusted to 7.0 with $\mathrm{HCl}$ or $\mathrm{NaOH}$ (Pan et al. 2009) where NR was used as sole carbon source. Previously isolated fungi were inoculated to different conical flasks containing MSM and kept for incubation for 2 months on rotary shaker. Fungi were incubated at $27 \pm 2{ }^{\circ} \mathrm{C}$; triplicates were maintained. After incubation period, NR discs were removed and observed for the growth of fungi. Then, NR discs were washed, dried at $50{ }^{\circ} \mathrm{C}$ in hot air oven for $24 \mathrm{~h}$, and weight loss was checked (Tsuchii and Tokiwa 2001).

Confirmation of natural rubber degradation by staining with Schiff's reagent

Evidence for degradation and mineralization of cis-1,4polyisoprene rubber hydrocarbon chain was obtained by staining-treated NR discs with Schiff's reagent. In a tightly stopper bottle, $10 \mathrm{ml}$ of fuchsin reagent was added to a sample and kept for incubation for 10-30 min at room temperature. After 10-30 min, excess amount of the reagent was discarded and $10 \mathrm{ml}$ of the sulphite solution was added in order to suppress non-specific reaction of untreated sample (Berekaa et al. 2000).

Confirmation of natural rubber degradation by scanning electron microscopy (SEM)

Evidence for degradation and mineralization of cis-1,4polyisoprene NR hydrocarbon chain was obtained by observing the NR discs under SEM. For the observation, NR discs buried in the soil and present in the MSM, which were subjected for degradation, were observed under field emission-scanning electron microscopy (FEI-SIRION, Eindhoven, Netherland) (Lions et al. 2000).

Confirmation of natural rubber degradation by Fourier transform-infrared spectroscopy (FTIR)

Chemical changes that arose directly on the NR surface as result of the degradation process were determined using FTIR spectroscopy. NICOLET 380 FTIR spectrophotometer from Thermo Fisher Scientific, France, was used, which gives transmittance spectra in IR range 4,000-400 nm. (Roy et al. 2005). 
Confirmation of natural rubber degradation by Nuclear Magnetic Resonance spectroscopy (NMR)

Structural changes that arose directly on the NR surface as result of the degradation process were determined using NMR spectroscopy. 400-MHz Supercon from Bruker, West Germany, with multi-nuclear probe commonly studies H1 NMR and ${ }^{13} \mathrm{C}$ NMR was used to study structural changes of rubber sample treated with microorganisms (Shah et al. 2008).

Characterization of enzymes responsible for biodegradation of natural rubber

It was studied that laccase and manganese peroxidase enzymes were responsible for the NR degradation.

Screening for laccase and manganese peroxidase enzyme production by Penicillium chrysogenum

Screening for laccase enzyme produced by $P$. chrysogenum was done on plates containing following composition $\left(\mathrm{g} \mathrm{l}^{-1}\right)$ : 3.0 peptone, 10.0 glucose, $0.6 \mathrm{KH}_{2} \mathrm{PO}_{4}, 0.001$ $\mathrm{ZnSO}_{4}, 0.4 \mathrm{~K}_{2} \mathrm{HPO}_{4}, 0.0005 \mathrm{FeSO}_{4}, 0.05 \mathrm{MnSO}_{4}, 0.5$ $\mathrm{MgSO}_{4}, 20.0$ Agar (pH-6) supplemented with $0.02 \%$ guaiacol. $P$. chrysogenum was inoculated into this plate, and the plate was incubated at $30{ }^{\circ} \mathrm{C}$ for 7 days. Laccase activity was visualized on plates containing $0.02 \%$ guaiacol, since laccase catalyses the oxidative polymerization of guaiacol to form reddish brown zones in the medium (Viswanath et al. 2008).

For the screening of manganese peroxidase enzyme producing organisms, $\mathrm{H}_{2} \mathrm{O}_{2}$ was added to the laccasescreening media.

Mass production of enzyme by submerged fermentation

Pure cultures of $P$. chrysogenum was inoculated to submerged state fermentation medium for the production of extracellular enzymes by using MSM media and was maintained at the incubation temperature of $27 \pm 2{ }^{\circ} \mathrm{C}$ for 3 months (Shraddha et al. 2011).

Determination of laccase and manganese peroxidase enzyme activity by using spectrophotometer

Guaiacol (2 mM) in sodium acetate buffer (10 mM pH 5.0) was used as substrate. The reaction mixture contained $3 \mathrm{ml}$ $10 \mathrm{mM}$ acetate buffer of $\mathrm{pH} 5,1 \mathrm{ml}$ guaiacol and $1 \mathrm{ml}$
Table 1 Weight loss of natural rubber by soil burial method

\begin{tabular}{llllll}
\hline $\begin{array}{l}\text { S1. } \\
\text { no. }\end{array}$ & $\begin{array}{l}\text { Number of } \\
\text { months }\end{array}$ & $\begin{array}{l}\text { Initial } \\
\text { weight } \\
(\mathrm{g})\end{array}$ & $\begin{array}{l}\text { Final } \\
\text { weight } \\
(\mathrm{g})\end{array}$ & $\begin{array}{l}\text { Weight loss } \\
(\mathrm{g})\end{array}$ & $\begin{array}{l}\text { Weight } \\
\text { loss in }(\%)\end{array}$ \\
\hline 1. & 2 & 3 & 2.84 & $0.16 \pm 0.01$ & 5.3 \\
2. & 4 & 3 & 2.63 & $0.37 \pm 0.04$ & 12.3 \\
3. & 6 & 3 & 2.12 & $0.88 \pm 0.01$ & 29.3 \\
\hline
\end{tabular}

Result are expressed in standard error, where $n=3$

enzyme source and enzyme blank contained $1 \mathrm{ml}$ of distilled water instead of enzyme source. The mixture was incubated at $30{ }^{\circ} \mathrm{C}$ for $15 \mathrm{~min}$, and absorbance was read at 450-nm blank using UV spectrophotometer (Papinutti and Martinez 2006). Manganese peroxidase enzyme activity was calculated by following laccase enzyme activity determination procedure, but for the reaction mixture, $1 \mathrm{ml}$ of $\mathrm{H}_{2} \mathrm{O}_{2}$ was added and incubated.

Protein estimation

Protein concentration was estimated to determine specific activity of enzyme. The protein concentration was determined by the Lowry's method, as described by Lowry's (1951) using bovine serum albumin (BSA) as a standard, absorbance was read at $660 \mathrm{~nm}$ using JENWAY- 6305 UV-Vis Spectrophotometer.

Partial purification of enzyme

The culture filtrates obtained were centrifuged, and supernatant was precipitated by salt precipitation technique by using different percent of ammonium sulphate. Culture filtrate got saturated at $70 \%$ saturation using ammonium sulphate, and then, it was dialysed against $50 \mathrm{mM}$ phosphate buffer ( $\mathrm{pH}$ 7.0) for $24 \mathrm{~h}$. SDS-PAGE electrophoresis was carried out for the partially purified enzymes, and the molecular weight was determined by using standard marker (Shraddha et al. 2011).

\section{Results and discussion}

Isolation of natural rubber degrading fungi

Rubber samples and the soil sample of 2, 4 and 6 months were plated on the potato dextrose agar medium, different fungi such as Aspergillus candidus, P. chrysogenum and Verticillium sp. were isolated and recorded. In the isolated 


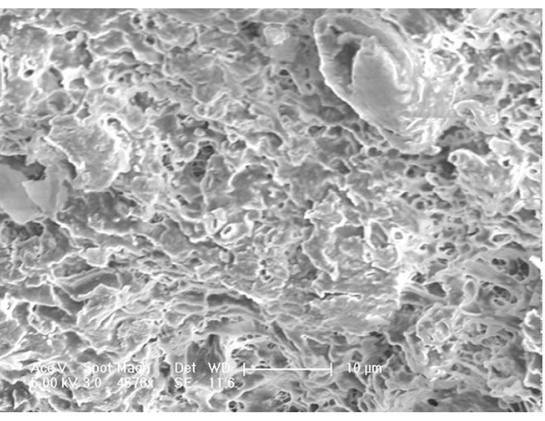

Buried in soil

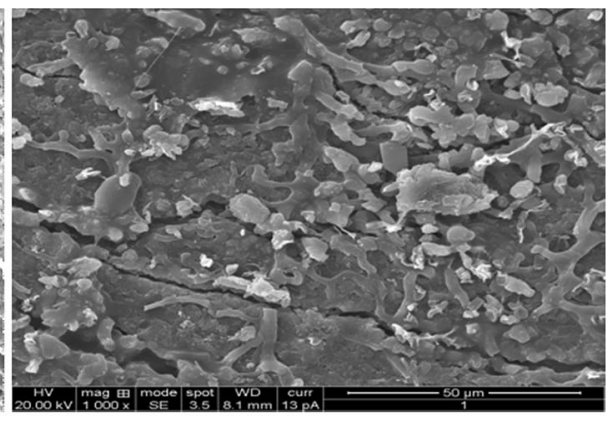

Penicillium chrysogenum treated

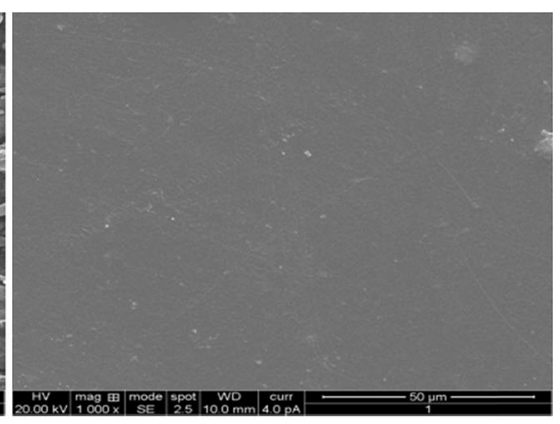

Control

Fig. 1 SEM images showing of natural rubber degradation

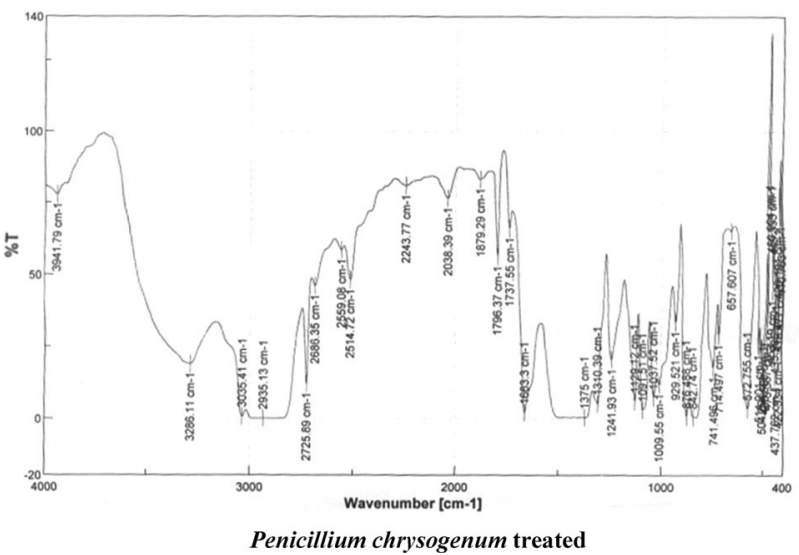

Fig. 2 Confirmation of natural rubber degradation by FTIR

organism, $P$. chrysogenum was pre-dominant and commonly isolated. Thus, it was screened to test NR-degrading ability. Weight loss was also observed in all the rubber samples, which was removed at different time interval (Table 1).

Plate assay for the screening of microorganisms capable of degrading natural rubber

In plate assay, weight loss was observed in $P$. chrysogenum inoculated NR discs, initial weight of the rubber disc was $10 \mathrm{~g}$ and final weight was $7.17 \mathrm{~g}$, and there was a decrease in $2.83 \pm 0.06 \mathrm{~g}$ weight and the percentage of weight loss was $28.3 \%$.

Screening of natural rubber degradation by using mineral salt medium (MSM)

Growth experiment was conducted by using MSM weight loss was observed, and growth of fungi was observed on

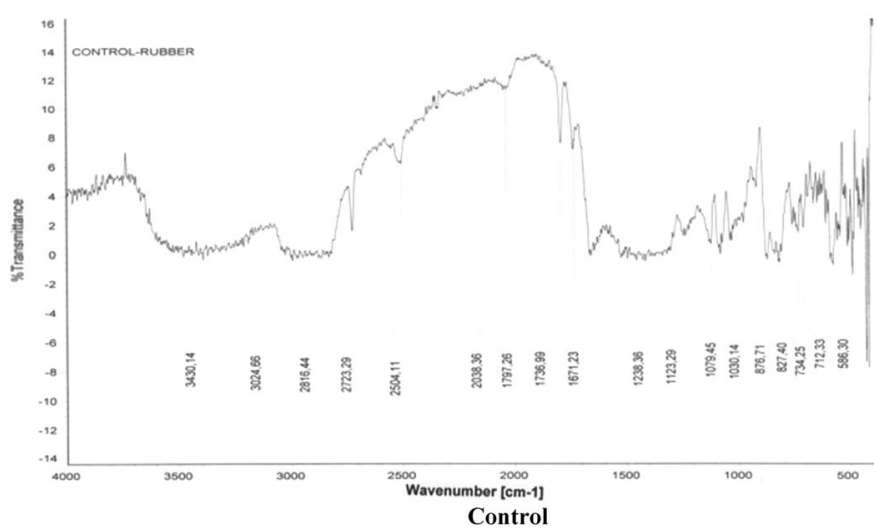

the NR discs. Initial weight of $P$. chrysogenum, inoculated sample, was $3 \mathrm{~g}$ and final weight was $1.07 \mathrm{~g}$, and there was a weight loss of $1.93 \pm 0.01 \mathrm{~g}$ and percentage of weight loss was $64.3 \%$.

Confirmation of rubber degradation by staining with Schiff's reagent

Natural rubber discs that were inoculated with microorganisms turned to purple colour, and there was no colour formation in the untreated control. Formation of purple colour in the treated sample was due to the presence of aldehyde and ketone group, which was produced as a result of degradation of cis-1,4-polyisoprene units of NR.

Confirmation of natural rubber degradation by scanning electron microscopy (SEM)

Natural rubber discs were observed under SEM; bio-film formation was observed and complete disintegration of the 

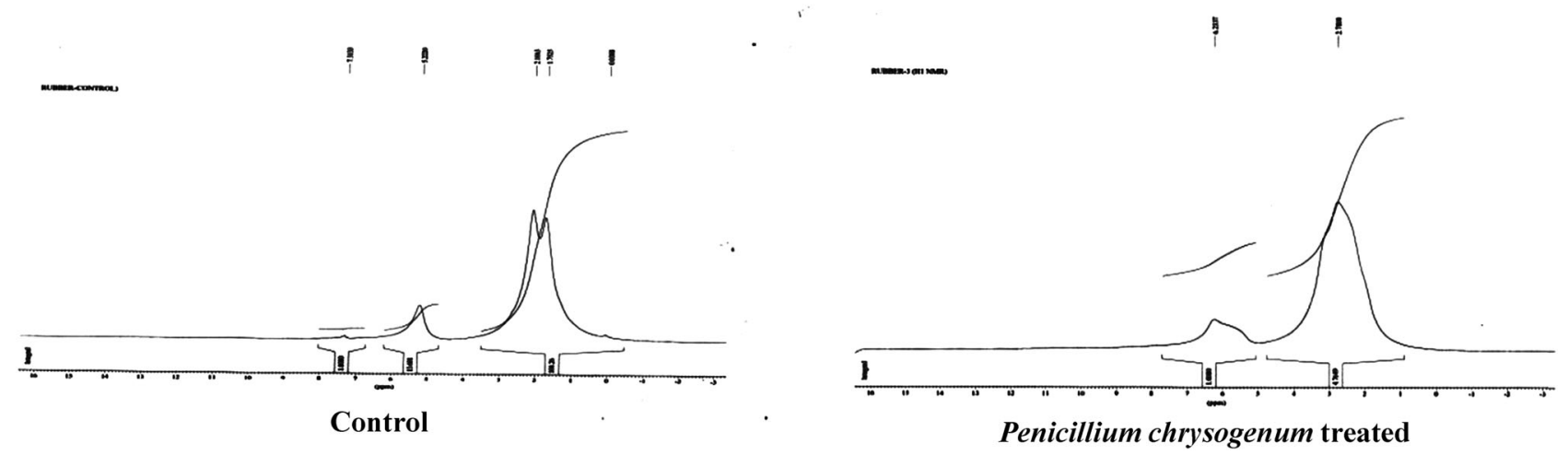

Fig. 3 Confirmation of natural rubber degradation by NMR

Table 2 Laccase and manganese peroxidase enzyme activity in I.U

\begin{tabular}{lllllllllllll}
\hline $\begin{array}{l}\text { Penicillium } \\
\text { chrysogenum }\end{array}$ & $\begin{array}{l}\text { 1st } \\
\text { week }\end{array}$ & $\begin{array}{l}\text { 2nd } \\
\text { week }\end{array}$ & $\begin{array}{l}\text { 3rd } \\
\text { week }\end{array}$ & $\begin{array}{l}\text { 4th } \\
\text { week }\end{array}$ & $\begin{array}{l}\text { 5th } \\
\text { week }\end{array}$ & $\begin{array}{l}\text { 6th } \\
\text { week }\end{array}$ & $\begin{array}{l}\text { 7th } \\
\text { week }\end{array}$ & $\begin{array}{l}\text { 8th } \\
\text { week }\end{array}$ & $\begin{array}{l}\text { 9th } \\
\text { week }\end{array}$ & $\begin{array}{l}\text { 10th } \\
\text { week }\end{array}$ & $\begin{array}{l}\text { 11th } \\
\text { week }\end{array}$ & $\begin{array}{l}\text { 12th } \\
\text { week }\end{array}$ \\
\hline $\begin{array}{l}\text { Laccase } \\
\begin{array}{c}\text { Manganese } \\
\text { peroxidase }\end{array}\end{array}$ & 0 & 0 & 0.0031 & 0.0052 & 0.0081 & 0.0111 & 0.0125 & 0.0161 & 0.0211 & 0.0247 & 0.0214 & 0.0182 \\
\hline
\end{tabular}

NR discs material and formation of cavities on the NR discs was also observed (Fig. 1).

Confirmation of rubber degradation by Fourier transform-infrared spectroscopy (FTIR)

Natural rubber discs, which were treated by fungi were subjected for FTIR studies peaks were observed at the wave length between $2,725.89$ and $1,662.34 \mathrm{~cm}^{-1}$ having $\mathrm{H}-\mathrm{C}=\mathrm{O}: \mathrm{C}-\mathrm{H}$ stretch and $\mathrm{C}=\mathrm{O}$ stretch, which indicates the presence of aldehydes and ketones, released as a result of NR degradation in the treated sample. Presence of these aldehyde and ketone group confirms NR degradation. Peaks showing the presence of aldehyde and ketone are absent in control (Fig. 2).

Confirmation of natural rubber degradation by nuclear magnetic resonance spectroscopy (NMR)

Structural changes that arose directly on the NR surface as result of the degradation process were determined using NMR spectroscopy. When rubber discs treated by microorganisms were subjected for NMR peaks showing the change in the structure of the rubber was observed. Presence of aromatic protons, $\mathrm{NH}$ protons, NH4 protons and aliphatic chains shows the degradation of NR by microorganisms, which was absent in control (Fig. 3).
Enzymatic studies of natural rubber degradation

It was studied that laccase and manganese peroxidase enzymes were responsible for the rubber degradation

Screening for laccase and manganese peroxidase enzyme production by Penicillium chrysogenum

Penicillium chrysogenum was inoculated on the laccase and manganese peroxidase medium; there was a formation of reddish brown colour around the colonies, as laccase and manganese peroxidase catalyses the oxidative polymerization of guaiacol to form reddish brown zone. $P$. chrysogenum which showed positive result for rubber degradation showed positive result for laccase and manganese peroxidase enzyme screening.

Spectrophotometrical analysis of laccase and manganese peroxidase enzyme activity

Penicillium chrysogenum showed more manganese peroxidase activity compared with laccase activity. Maximum activity of both laccase and manganese peroxidase enzyme activity was maximum in 10th week. Laccase enzyme activity in 10th week was 0.0247 I.U, and manganese peroxidase activity in 10th week was 0.0262 I.U (Table 2; Fig. 4). 
Fig. 4 Laccase and manganese peroxidase enzyme activity in I.U
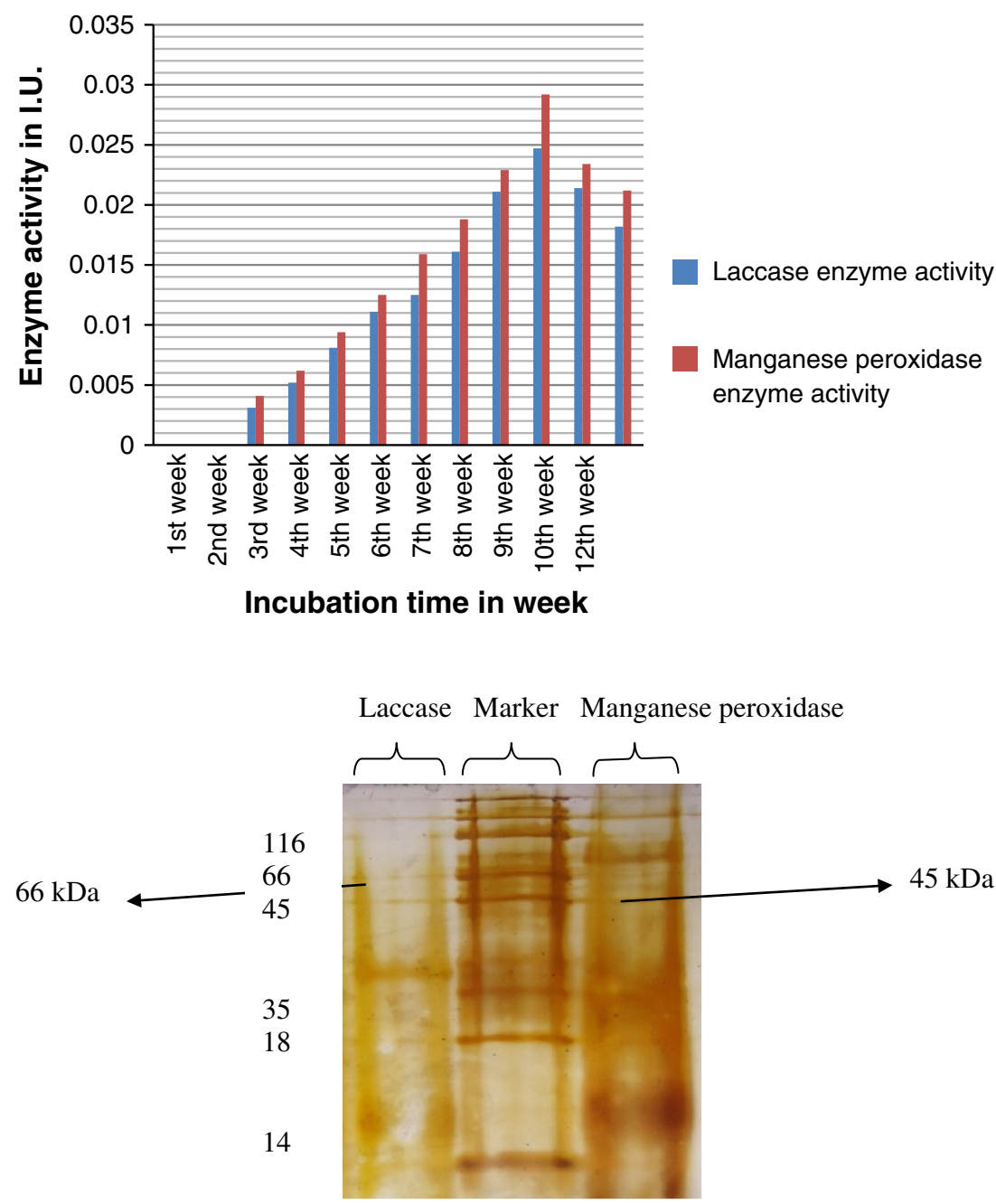

Fig. 5 Molecular weight of laccase and manganese peroxidase enzyme of Penicillium chrysogenum
Protein estimation

Specific activity of laccase enzyme in $P$. chrysogenum was $0.247 \pm 0.002 \mu \mathrm{mol} / \mathrm{ml} / \mathrm{min} / \mathrm{mg}$, and specific activity of manganese peroxidase enzyme in $P$. chrysogenum was $0.291 \pm 0.002 \mu \mathrm{mol} / \mathrm{ml} / \mathrm{min} / \mathrm{mg}$.

Partial purification of enzyme

By performing SDS-PAGE, molecular weight of laccase and manganese peroxidase enzyme of $P$. chrysogenum was determined. In present work, approximate molecular weight of laccase enzyme was $66 \mathrm{kDa}$ and manganese peroxidase was $45 \mathrm{k}$ Da (Fig. 5).

Similar attempts were made by several other scientists to degrade rubber by using microorganisms.

Roy et al. (2005) made an attempt to study on NR biodegradation through solid-state fermentation (SSF) and submerged fermentation (SMF) has been carried out for both bacterial as well as fungal species. There was a change in the organic carbon content along with the average molecular weight of the treated rubber samples indicated rubber hydrocarbon utilization and its degradation. Presence of aldehydic group as proved through Schiff's staining and from IR spectra along with increase in unsaturation, intensities indicated degradation in both SSFand SmF-treated rubber. Degradation was also confirmed by SEM studies.

Berekaa et al. (2000) conducted similar work and tested the biodegrading ability of different bacteria belonging to the genera Gordonia (strains Kb2, Kd2 and VH2), Mycobacterium, Micromonospora and Pseudomonas. All strains were able to use NR as well as NR latex gloves as sole carbon source.

Fungi-degrading NR was isolated from soil and deteriorated tyres. In connection with studies on decomposition 
of NR, numerous investigations have been made with microorganisms. The early studies were carried out to prevent degradation of rubber in soil. For instance, Spicaria violacea CMI1 17109 was isolated by Kitchin from rubber underground insulators. Some of these insulators were completely deteriorated after 39 months in the soil. Afterwards, investigations were made to improve the elimination of worn out rubber. Attempts by Faber to grow Fusarium solani upon vulcanized rubber tyres were reported (Borel et al. 1981).

Shraddha et al. (2011) showed that laccase enzymes have gained great importance in industries; laccases are one among them, which are widely present in the nature. Laccases are the oldest and most studied enzymatic systems. These enzymes contain $15-30 \%$ carbohydrate and have a molecule mass of $60-90 \mathrm{kDa}$.

Molecular weight of manganese peroxidase ranges from 40 to $48 \mathrm{kDa}$. Two different laccase isoenzymes with the same molecular mass $(67 \mathrm{kDa})$ and $\mathrm{N}$-linked carbohydrate content $(3 \%)$ and a slight difference in their $\mathrm{p} I$ values (3.41 and 3.48) were characterized. In addition, two different $\mathrm{MnP}$ isoenzymes with the same molecular mass $(47 \mathrm{kDa})$ and N-linked carbohydrate content $(4 \%)$ and different $\mathrm{p} I$ values (3.35 and 3.45) were characterized. Both enzymes showed good stability at $25^{\circ} \mathrm{C}$ and over a wide range of $\mathrm{pH}$. Both laccases oxidize ABTS (2,2 azino-bis(3ethylbenzthiazoline-6-sulphonic acid) more efficiently than 2,6-dimethoxyphenol (DMP) with similar efficiency values $(K \mathrm{cat} / K \mathrm{~m})$ while the $\mathrm{MnP} \mathrm{I}$, the major peroxidase isoenzyme in the studied conditions, oxidizes the $\mathrm{Mn}^{2+}$ - and Mn-mediated activity on DMP more efficiently than MnP II. (Papinutti and Martinez 2006).

\section{Conclusion}

Rubber products are widely used in our daily life. These products are made up of natural vulcanized rubber and other chemical additives. Due to vulcanization of the NR, these rubber are very resistant to high temperature and persist in environment for very long time. Rubber materials have been increasingly used now a days in different area after usage its disposal is a very big solid waste problem. It can not be easily recycled due to the sulphur cross-linking formed during vulcanization. If they are burnt, they release enormous amount of carbon-di-oxide and some other gases, which causes environmental pollution and contribute to the global warming. Rubber products such as balloon, which are disposed in the natural environment, are considered to be dangerous to wild animals if they are consumed by animals.
So, one of the alternative way to solve these problems is to subject these product to biodegradation. During the present study, rubber discs were dumped in the soil were removed at regular interval of time and then plated on the media to isolate the microorganisms. In isolated organism, $P$. chrysogenum effectively degraded the rubber sample. The present study has showed that it is possible to use $P$. chrysogenum and enzymes are responsible for degradation of NR effectively.

Acknowledgments This work was supported Kuvempu University, Jnanasahyadri, Shankaraghatta-577451, Shivamogga (Dist.), Karnataka, India. I thank Indian Institute of Science, Bangalore, for supporting us to complete SEM, FTIR, and NMR work.

\section{References}

Berekaa MM, Lions A, Reichelt R, Keller U, Steinbuchel A (2000) Effect of pretreatment of rubber material on its biodegradability by various rubber degrading bacteria. FEMS Microbiol Lett 184:199-206

Borel M, Kergomard A, Renard F (1981) Degradation of natural rubber by fungi imperfecti. Agric Biol Chem 46:877-881

Domsch KH, Gams W, Anderson TH (1980) Compendium of soil fungi, vol 1. Academic Press, New York, pp 1-859

Ellis MB (1971) Dematiaceous hyphomycetes. Common wealth mycological institute, Kew, pp 1-608

Ellis MB (1976) More dematiaceous hyphomycetes. Common wealth mycological institute, Kew, pp 1-507

Ellis MB, Ellis JP (1997) Microfungi on land plants: an identification handbook. Croom Helm, London, p 868

Gilman JC (2001) A manual of soil fungi, 2nd edn. Biotech Books, New Delhi, pp 1-392

Lions A, Rudolf Reichelt R, Keller U, Steinbuchel A (2000) A Gram negative bacterium identified as Pseudomonas aeruginosa, AL98, is a potent degrader of natural rubber and synthetic cis1,4-polyisoprene. FEMS Microbiol Lett 182:155-161

Lowry OH, Rosebrough NJ, Farr AL, Randall RJ (1951) Protein measurement with the Folin phenol reagent. J Gen Microbiol 31:3017-3027

Nagamani A, Kunwar IK, Manoharachary C (2006) Handbook of soil fungi. I. K. International Pvt. Ltd., New Delhi, pp 1-477

Pan L, Gung GJ, Yin B, Cheng PS (2009) Contribution to deterioration of polymeric materials by slow growing bacteria Nocardia corynebacterioides. Int J Biodeterior Biodegradation 63:24-29

Papinutti L, Martinez JM (2006) Production and characterization of laccase and manganese peroxidase from the ligninolytic fungus Fomes sclerodermeus. J Technol Biotechnol 81:1064-1070

Pitt JI (1979) The genus Penicillium and its teleomorphic states Eupencillium and Talaromyces. Academic Press, London, pp 1-634

Roy VR, Das M, Banrjee R, Bhowmick A (2005) Comparative studies on rubber biodegradation through solid state and submerged fermentation. Process Biochem 42:181-186

Shah AA, Hasan F, Hameed A, Ahmed S (2008) Biological degradation of plastics: a comprehensive review. Biotechnol Adv 26(246):265 
Shraddha, Shekher R, Sehgal S, Kamtania M, Kumar A (2011) Laccase microbial source production, purification, potential biotechnological application. Enzym Res 1-11

Subramanian CV (1983) Hyphomycetes, taxonomy and biology. Academic Press, New York, pp 410-461

Tsuchii A, Tokiwa Y (2001) Microbial degradation of tire rubber particles. Biotechnol Lett 23:963-969
Tsuchii A, Takeda K, Suzuki T, Tokiwa Y (1996) Colonization and degradation of rubber pieces by Nocardia species. Biodegradation J 7:41-48

Viswanath B, Chandra MS, Pallavi H, Reddy BR (2008) Screening and assessment of laccase producing fungi isolated from different environmental samples. Afr J Biotechnol 7:1129-1133 